\title{
EXPERIMENTAL DETERMINATION OF THE EFFECTIVE PRESSURE COEFFICIENTS FOR BRAZILIAN LIMESTONES AND SANDSTONES
}

\author{
Guilherme Fernandes Vasquez ${ }^{1}$, Eurípedes do Amaral Vargas Junior², \\ Cleide Jeane Bacelar Ribeiro ${ }^{3}$, Marcos Leão ${ }^{4}$ and Julio Cesar Ramos Justen ${ }^{5}$ \\ Recebido em 11 junho, 2008 / Aceito em 26 janeiro, 2009 \\ Received on June 11, 2008 / Accepted on January 26, 2009
}

\begin{abstract}
There are numerous efforts to obtain information about saturation and pressure changes due to reservoir production from time-lapse seismic data. In spite of some good examples existing on the literature, there are a lot of approximations behind those studies. Generally, it is assumed that the seismic properties are functions of saturation and differential pressure $P_{d}$ (overburden minus fluid pressure). Actually, the stress that governs the seismic behavior is the effective stress $P_{e f}$, which is not exactly equal to $P_{d}$. In fact it is equal to the overburden stress minus $n$ times the fluid pressure. Such coefficient $(n)$ is known as the effective stress coefficient. Sometimes, depending on the circumstances, it might be identified as the Biot-Willis coefficient taking into consideration the bulk modulus of the porous media. In this paper, laboratory results in a tentative to quantify the $n$ values for Brazilian limestones and tight sands will be presented. It is important to point out, that is the first effort to perform this sort of measurements on Brazilian rocks. The results have shown that the mentioned approximations can introduce errors on pressure estimations from time-lapse data even for high porosity rocks.
\end{abstract}

Keywords: effective pressure, porepressure, seismic velocities, Biot-Willis coefficient, 4D seismic.

RESUMO. Há vários esforços no sentido de obter informações sobre mudanças de saturação e pressão, devidas à produção dos reservatórios, a partir de dados sísmicos com lapso de tempo. A despeito de alguns bons exemplos existentes na literatura especializada, várias aproximações são feitas para a realização destes estudos. Geralmente, é assumido que as propriedades sísmicas são funções da saturação e da pressão diferencial $P_{d}$ (pressão de soterramento menos pressão de fluido). Na verdade, a tensão que determina o comportamento sísmico é a tensão efetiva $P_{e f}$, que não é exatamente igual a $P_{d}$. De fato, esta é igual à tensão de soterramento menos $n$ vezes a pressão de fluido. Tal coeficiente $n$ é conhecido como coeficiente de tensão efetiva. Eventualmente, a depender das circunstâncias, este pode ser identificado com o coeficiente de Biot-Willis considerando o módulo de compressão volumétrica do meio poroso. Neste trabalho serão apresentados resultados de medidas em laboratório procurando quantificar os valores de $n$ para calcários e arenitos fechados brasileiros. É importante salientar que este é o primeiro esforço de realização deste tipo de medidas em rochas brasileiras. Os resultados mostram que as aproximações mencionadas podem introduzir erros nas estimativas de pressão a partir de dados de monitoramento sísmico mesmo para rochas muito porosas.

Palavras-chave: pressão efetiva, poro-pressão, velocidades sísmicas, coeficiente de Biot-Willis, sísmica 4D.

\footnotetext{
${ }_{1}^{1}$ Petrobras / UFRJ, Departamento de Geologia, Centro de Pesquisas e Desenvolvimento Leopoldo A. Miguez de Mello, Avenida Horácio Macedo, 950, Cidade Universitária, Ilha do Fundão, 21941-915 Rio de Janeiro, RJ, Brazil. Phone: +55 (21) 3865-6457; Fax: +55 (21) 3865-4739 - E-mail: vasquez@petrobras.com.br

2PUC-Rio / UFRJ, Pontifícia Universidade Católica do Rio de Janeiro, Centro Técnico-Científico, Departamento de Engenharia Civil, Rua Marques de São Vicente, 225, Gávea, 22453-900 Rio de Janeiro, RJ, Brazil. Phone: +55 (21) 3114-1188; Fax: +55 (21) 3114-1195 - E-mail: vargas@puc-rio.br

${ }^{3}$ Fundação Gorceix, Centro de Pesquisas e Desenvolvimento Leopoldo A. Miguez de Mello, Avenida Horácio Macedo, 950, Cidade Universitária, Ilha do Fundão, 21941-915 Rio de Janeiro, RJ, Brazil. Phone: +55 (21) 3865-4296; Fax: +55 (21) 3865-4739 - E-mail: cleide.gorceix@petrobras.com.br

${ }^{4}$ Petrobras, Centro de Pesquisas e Desenvolvimento Leopoldo A. Miguez de Mello, Avenida Horácio Macedo, 950, Cidade Universitária, Ilha do Fundão, $21941-915$ Rio de Janeiro, RJ, Brazil. Phone: +55 (21) 3865-6409; Fax: +55 (21) 3865-4739 - E-mail: marleao@petrobras.com.br

5 Petrobras, Centro de Pesquisas e Desenvolvimento Leopoldo A. Miguez de Mello, Avenida Horácio Macedo, 950, Cidade Universitária, Ilha do Fundão, $21941-915$ Rio de Janeiro, RJ, Brazil. Phone: +55 (21) 3865-4387; Fax: +55 (21) 3865-4739 - E-mail: jcesar@petrobras.com.br
} 


\section{INTRODUCTION}

It is well known that the stress state influences the mechanical and petrophysical properties of rocks. Porosity, permeability and seismic velocities may be strongly dependent on the stress magnitude and orientation. It was considered in the study only the simple case of hydrostatic stress, herein referred as pressure. Saturation state is other great factor acting on mechanical properties variation. In time-lapse studies, both states can change in different ways and combinations, leading to a kind of puzzle for the geoscientists to distinguish what effect are governing the different seismic response between two surveys.

To our knowledge, every trial to obtain porepressure variation from time-lapse seismic has been done considering the assumption of an effective pressure $P_{e f}$ equal to the differential pressure $P_{d}$, that is:

$$
P_{e f}=P_{d} \approx P_{c}-P_{p}
$$

This assumption agrees with the effective stress concept introduced by Terzaghi in 1923 as being the excess of the total stress over the neutral stress (porepressure) that acts exclusively in the solid phase of soils (Skempton, 1960), and "all the measurable effects of a change in stress, such as compression, distortion, and a change in shearing resistance, are due exclusively to changes in the effective stress" (Terzaghi et al., 1996).

This concept had been modified to include any linear combination of confining and porepressure that allows the reduction of independent variables (Lade \& de Boer, 1997). If we consider some physical property of a porous media that depends on the total stress (here confining pressure), it will be also dependent on porepressure, that acts hydrostatically over all the grain free surfaces,

$$
Q=Q\left(P_{c}, P_{p}\right)
$$

The effective pressure would be a linear combination

$$
P_{e f}=P_{c}-n P_{p}
$$

such that

$$
Q=Q\left(P_{c}, P_{p}\right)=Q\left(P_{e f}\right)
$$

The coefficient $n$ is the so-called porepressure coefficient or effective pressure coefficient (Biot, 1955; Christensen \& Wang, 1985).

Nur \& Byerlee (1971) had shown that, for the volumetric bulk compression of a porous media, the coefficient $n$ is equal to the Biot-Willis coefficient (Biot \& Willis, 1957),

$$
n=1-\frac{K_{d r y}}{K_{s o l}}
$$

where $K_{d r y}$ and $K_{s o l}$ are the bulk moduli of the dry rock and the solid fraction, respectively (the inverse of the compressibility). Todd \& Simmons (1972), studying the pressuredependence of seismic velocities of rocks, concluded that, for the compressional-wave velocity, this porepressure coefficient can be written as

$$
n=1-\frac{\left(\partial V_{p} / \partial P_{p}\right)_{P_{d}}}{\left(\partial V_{p} / \partial P_{d}\right)_{P_{p}}}
$$

where $\left(\partial V_{p} / \partial P_{p}\right)_{P_{d}}$ and $\left(\partial V_{p} / \partial P_{d}\right)_{P_{p}}$ are the partial derivatives of the velocity with respect to the porepressure for constant differential pressure and to the differential pressure for constant porepressure, respectively. These derivatives may be obtained from special velocity measurement experiments on the lab, and this $n$ might be interpreted as an empirical porepressure coefficient. This empirical $n$ can be extended to any physical property $Q$ as

$$
n=1-\frac{\left(\partial Q / \partial P_{p}\right)_{P_{d}}}{\left(\partial Q / \partial P_{d}\right)_{P_{p}}}
$$

A coefficient $n=1$ means that the porepressure compensates the effect of confining pressure, while $n<1$ means that the effect of confining pressure is greater than that of porepressure and $n>1$ means that the porepressure surpasses the confining pressure effect. There are some reported results on the determination of $n$, however they are far from being conclusive. For instance, King (1966) found $n$ values greater than unity for the compressional and shear-wave velocities on Boise, Bandera, Berea and Torpedo sandstones. Whereas Christensen \& Wang (1985) found $n$ values less than unit for compressional-wave velocity and bulk modulus, but greater than unity for shear-wave velocity and Poisson's ratio of Berea sandsone. Prasad \& Manghnani (1997) as well as Xu et al. (2006) found effective pressure coefficients $n<1$ for Berea, Michigan and Lyons sandstones. Such a variety of results indicates that the behavior of $n$ with pressure and petrophysical properties needs further investigation.

Gurevich (2004) discussed the validity of the effective stress concept and concluded that, for a rock with homogeneous and linearly elastic solid phase the coefficient $n$ for the seismic velocities must be equal to 1 . He claims that the violation of the homogeneity and linear elastic behavior of the grains may be the reason of the different experimental results. Berryman (1992, 1993) derived effective stress coefficients for various properties of rocks composed of different mineral constituents, showing that each physical quantity may be governed by a particular effective stress associated with a given effective stress coefficient. 


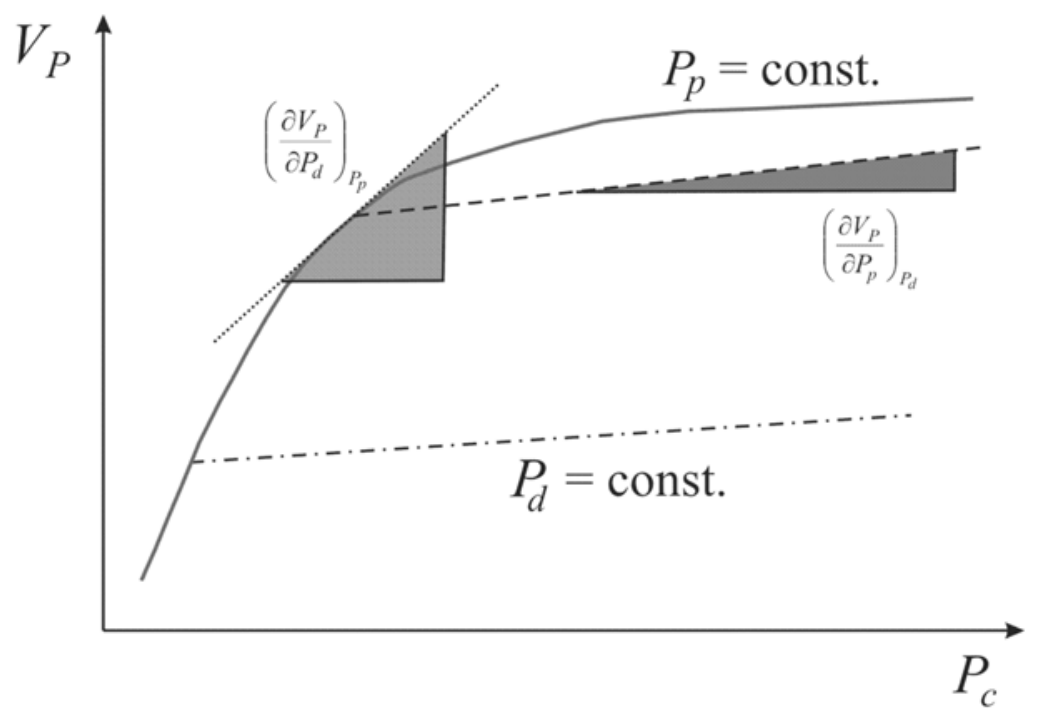

Figura 1 - Schematic diagram illustrating how to compute the derivatives on the numerator and denominator in the experimental equation for the effective-stress coefficient (Eq. (6)). The numerator is calculated from the slope of the $V_{P}-P_{c}$ curve at constant $P_{d}$, and the denominator is calculated from the slope of the tangent of $V_{P}-P_{c}$ at constant $P_{p}$. Note that $V_{P}$ could be replaced with any rock property.

Besides time-lapse seismic, geopressure prediction on petroleum exploration also assumes that the effective stress is equal to the differential pressure. This is a very important issue, since "subsurface geopressures are often the dominant decision variable in the selection of drilling fluids and wellbore casings, which are two of the largest costs in most drilling programs. Underdesigning the drilling fluid or casing program can result in unplanned expenses, nonproductive time due to fluid influx, fluid loss or wellbore instability, inability to reach total depth, and even catastrophic environmental damage, blow-outs, or rig fires" (Standifird et al., 2004).

\section{METHOD}

It were measured the elastic velocities at ultrasonic frequencies on the laboratory by the pulse transmission technique (Vasquez et al., 2000) on a set of limestone and sandstone samples. The samples were saturated with brine to simulate the in situ formation water (65000 ppm of NaCl for the limestone and 240000 ppm for the tight sand).

The velocities were measured varying the confining pressure from atmospheric up to $6000 \mathrm{psi}$. The porepressure was increased until 4000 psi in $500 \mathrm{psi}$ steps. On the other hand in some samples it was used $8000 \mathrm{psi}$ for the final confining pressure.

From the experimental data, it was derived empirical porepressure coefficients for compressional-wave and shear-wave velocities and also for the bulk and shear moduli. The empirical coefficients were derived using Equation (5), through the scheme illustrated on Figure 1. Note that a constant differential pressure curve with positive slope corresponds to $n$ less than unity, while those with negative slope correspond to $n$ greater than 1 . The case in which $n=1$ corresponds to a perfect horizontal " $P_{d}=$ constant" curves (Vasquez et al., 2007).

In order to obtain the derivatives of velocities and moduli related to a confining pressure, it had been fitted the data points with functions generally used to describe the velocity-pressure behavior of rocks, especially the Mavko (2004) and Eberhart-Phillips et al. (1989):

$$
V(P)=a_{M}-b_{M} \exp \left(-\frac{P}{c_{M}}\right)
$$

and

$$
V(P)=a_{H}+b_{H}-P-c_{H} \exp \left(-d_{H} P\right)
$$

respectively. Similar pressure laws were used for the bulk and shear moduli. The results obtained with these different pressure laws were very consistent (both fitted functions are shown in figures illustrating velocities and moduli as a function of confining pressure as large and small dashed lines, and they are almost always coincident, as can be seen on those pictures).

It is important to notice that the bulk modulus of the pore fluid varies with the porepressure. In order to remove this effect from the data, it was also derived a normalized bulk modulus and its 
corresponding effective-pressure coefficient. The effect of fluid changes was removed using Gassmann's equation (Gassmann, 1951):

$$
\begin{gathered}
\frac{K_{N}}{K_{s o l}-K_{N}}=\frac{K_{s a t}}{K_{s o l}-K_{s a t}} \\
-\frac{1}{\phi}\left[\frac{K_{f l}}{K_{s o l}-K_{f l}}-\frac{K_{f l N}}{K_{s o l}-K_{f l N}}\right]
\end{gathered}
$$

were $K_{N}$ is the desired normalized bulk modulus, $K_{\text {sat }}$ is the measured bulk modulus with rock saturated with fluid which bulk modulus is $K_{f l}$, and $K_{f l N}$ is the fluid bulk modulus used as the reference for normalization. It was used the lowest porepressure as the reference saturation state. The fluid properties were obtained from the relations published by Batzle \& Wang (1992). This approach does not take into account frequency related effects on seismic velocities.

\section{SAMPLE SET}

The samples selected for this study comprises unconsolidated to medium consolidated limestones and a set of tight sandstones.

The limestones are calcirudite to rhodolite with a matrix that varies from micritic to calcarenitic. Some samples have also siliciclastic grains (mainly quartz). The occurrence of macro-foraminifera is common as well. Since these limestones were not very well consolidated, the samples were covered with metal jackets with pervious screens at the ends to avoid sample degradation during cleaning as well as petrophysical and acoustic measurements. Although this jacketing process had been proved not to change the velocities measurements, in some cases the quality of waveform signal is very poor, especially for the shear wave in saturated samples. Due to these difficulties, it was not possible to pick a complete set of measurements unless on three samples (5005, 5062 and 5070). On the other hand, compressional-wave data collection was possible on six samples. The petrophysical properties of the samples are listed in Table 1. Figure 2 illustrates photos from thin sections representing two of the limestone samples and a scanning electron microscopy (SEM) showing the existence of complex micro porosity on these rocks.

Table 1 - Petrophysical properties of the limestone samples.

\begin{tabular}{|c|c|c|c|}
\hline Sample & $\rho_{\mathrm{ma}}(\mathrm{g} / \mathrm{cc})$ & $\phi(\%)$ & $\kappa(\mathrm{md})$ \\
\hline 5001 & 2.71 & 23.15 & 2.25 \\
\hline 5005 & 2.75 & 29.74 & 7.63 \\
\hline 5057 & 2.70 & 33.52 & 1097.9 \\
\hline 5062 & 2.72 & 30.78 & 1237.05 \\
\hline 5070 & 2.67 & 26.24 & 34.11 \\
\hline 5088 & 2.71 & 26.46 & 225.17 \\
\hline
\end{tabular}
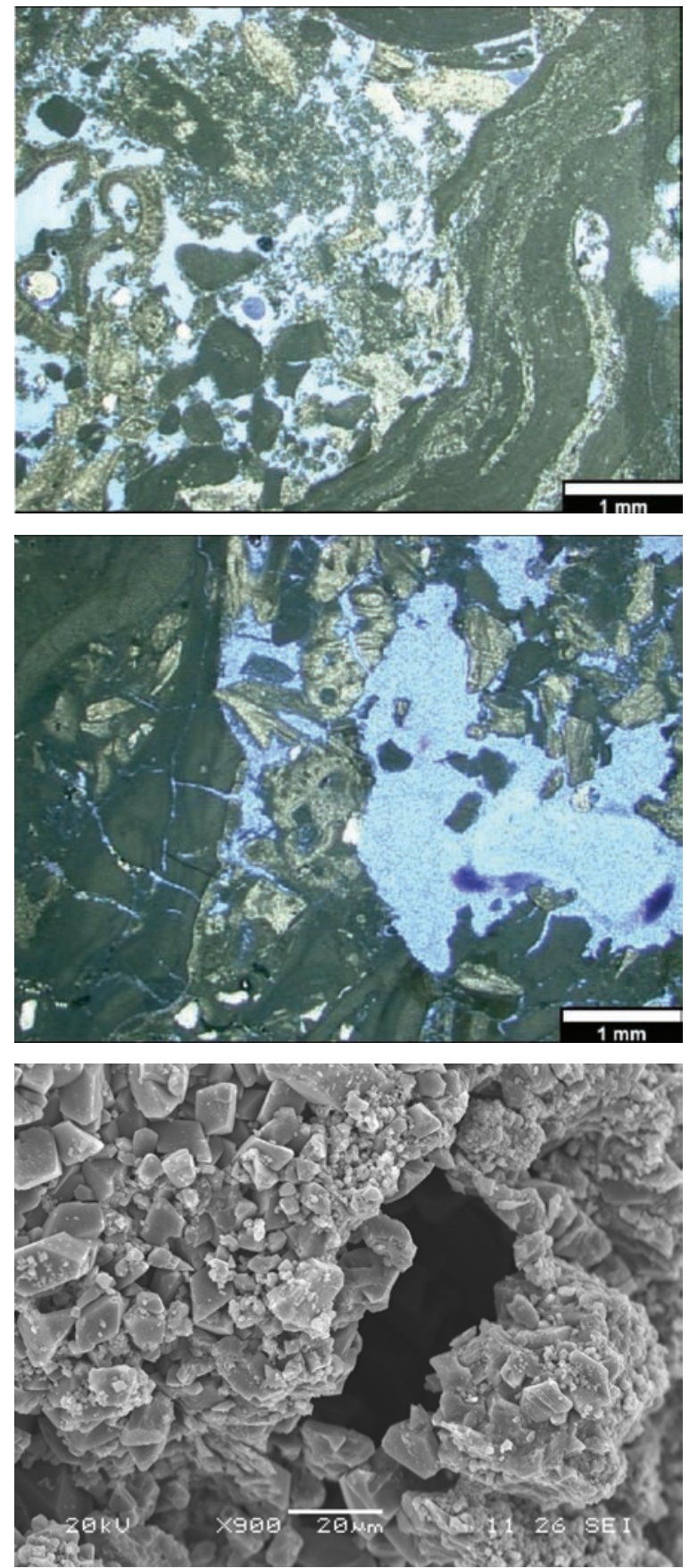

Figure 2 - (a) Optical microscopy photo of the limestone sample 5005. This is a calcirudite with calcarenitic matrix, with intergranular porosity. (b) Thin section from sample 5062, biolitite to red algae with vugular porosity. (c) SEM image of sample 5062.

The sandstones samples are well consolidated arkosic sandstones, with more than 50\% Feldspar on average, fine to medium grained, poorly to moderately sorted, and relatively rich in chlorite, especially as fringes around the grains. As usual on consolidated samples, the signal quality was very good even for the sa- 
turated samples. The petrophysical properties of the sandstones are listed on Table 2. Note that the porosity of these sandstones is large mainly due to the micro porosity associated to the presence of chlorite. In this sense, it may be considered tight sandstone. Figure 3 shows thin sections images of the sandstone facies, with detail of the fringes as well as a SEM image illustration the grain boundaries.

Table 2 - Petrophysical properties of the sandstone samples.

\begin{tabular}{|c|c|c|c|}
\hline Sample & $\rho_{\mathrm{ma}}(\mathrm{g} / \mathrm{cc})$ & $\phi(\%)$ & $\kappa(\mathrm{md})$ \\
\hline 5965 & 2.66 & 18.50 & 0.90 \\
\hline 5976 & 2.65 & 15.20 & 8.66 \\
\hline 6047 & 2.65 & 13.20 & 11.17 \\
\hline 6090 & 2.65 & 19.40 & 14.46 \\
\hline 6125 & 2.65 & 18.00 & 16.04 \\
\hline 6492 & 2.66 & 16.50 & 0.31 \\
\hline
\end{tabular}

\section{RESULTS}

\section{Carbonates}

In Figure 4 it can be observed an example of compressional-wave velocity versus confining pressure curves for the sample 5005, with the zero porepressure curves (dots) along with the velocity data for distinct differential pressure values. Actually, zero porepressure means atmospheric pressure (14.7 psi or $0.1 \mathrm{MPa}$ ). The data for low differential pressure (1000 psi or $6.89 \mathrm{MPa}$ ) shows some dispersion around the fitted line. It was also noticed that data for high differential pressure suggests $n$ values higher than unity. In principle the velocity curves for different porepressure values would be "parallel" to each other if the porepressure coefficient was equal to unit. From Figure 5, which shows the velocity versus confining pressure for different porepressure values for sample 5005, it becomes evident that $n$ is not equal to 1 .

The measurements were repeated successively with different stress paths and in some limestone samples the repeatability was not as good as expected. These "bad results" were associated with sample destruction, maybe due to pressure cycling and calcite dissolution. Since calcite is more soluble in brine than in fresh water we could try to avoid this problem using a tampering solution. In some samples there were strong evidences that the dissolution was followed by migration of thin particles and subsequent obliteration of the pore space and permeability reduction. From an initial selection of ten samples, four were destroyed by these procedures. Of course, these "bad results" were abandoned through our study, since the samples lost the integrity during the experiment.
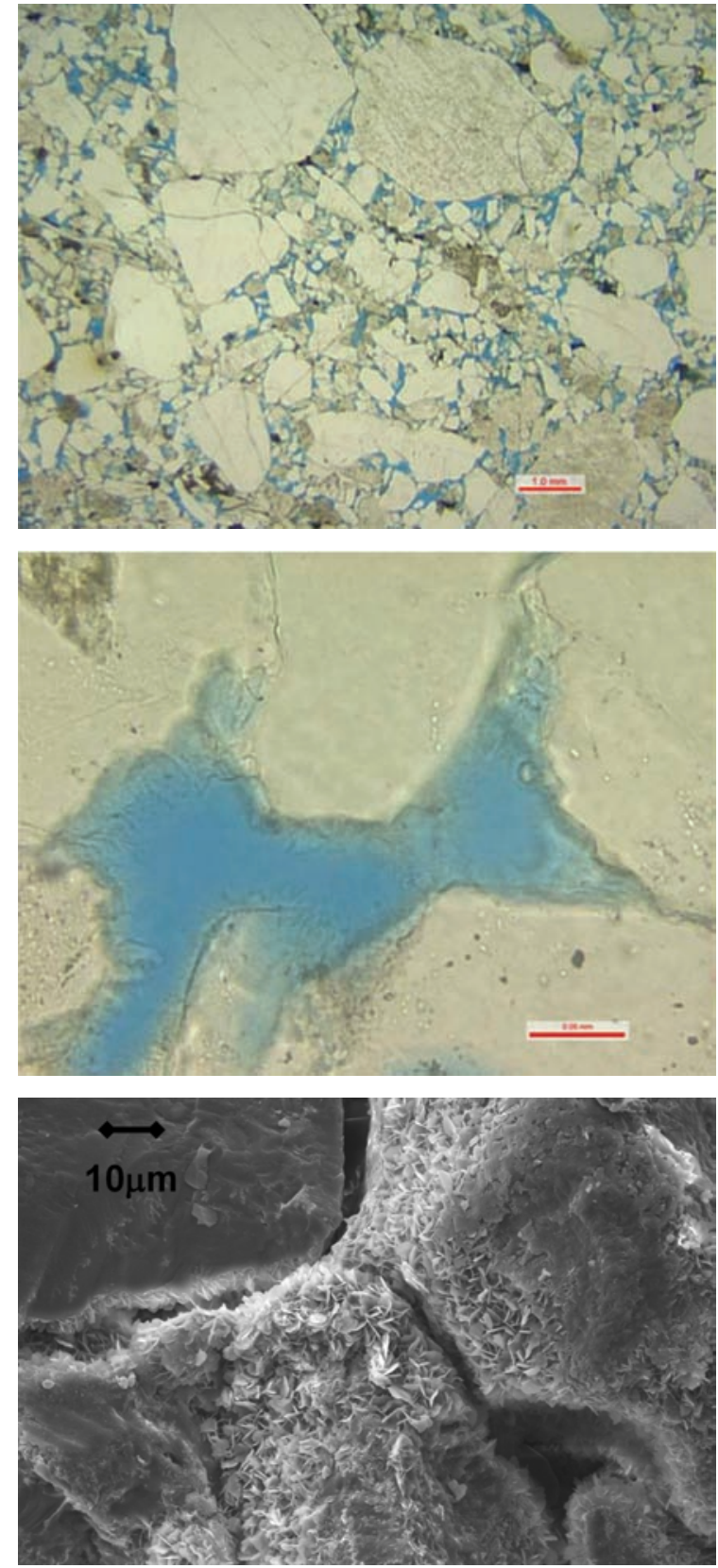

Figure 3 - (a) Typical thin section image of the sandstone samples. This is a fine to medium grained sandstones, poorly sorted with disperse large grains. (b) Detail of the grain boundaries with chlorite fringes. (c) SEM image of sample 5965.

The rock bulk modulus as a function of confining pressure for the same sample 5005, along with the constant differential pressure curves is shown on Figure 6. In Figure 7 the curves obtained for the bulk modulus after the normalization process represented by Equation (10) are presented. The dots represent the normalized bulk modulus as a function of confining pressure for zero porepressure, and the other curves are the constant differential 
pressure curves. It is worth to point out that the normalization of the bulk modulus leads to effective pressure coefficients close to one for moderate and low differential pressure values. This effect was present on the other samples as well: the $n$ values corresponding to the normalized bulk modulus is equal or very close to unity. In general, for higher differential pressures (and confining pressure) $n$ tends to be greater than unit.

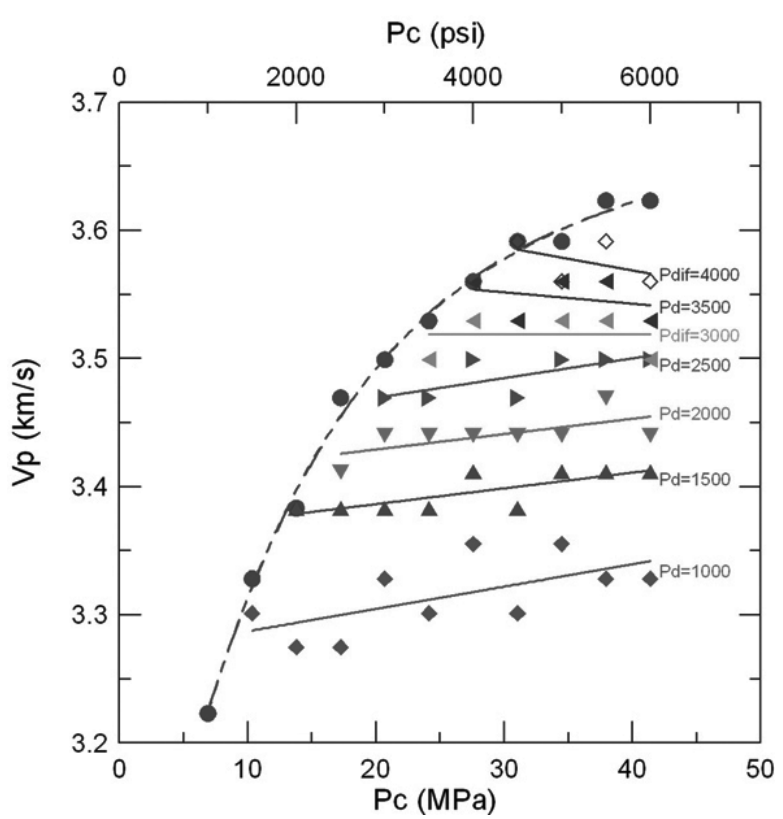

Figure 4 - Velocity curves for sample 5005 as a function of confining pressure for zero porepressure (dots) along with constant differential pressure curves.

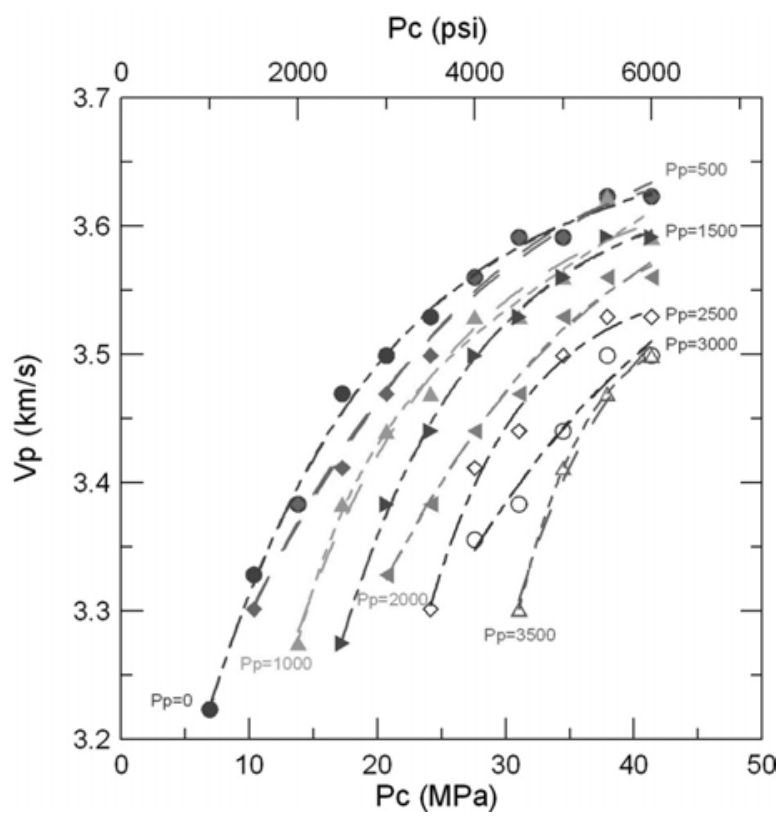

Figure $\mathbf{5}$ - Velocity curves for sample 5005 as a function of confining pressure for different porepressure values.

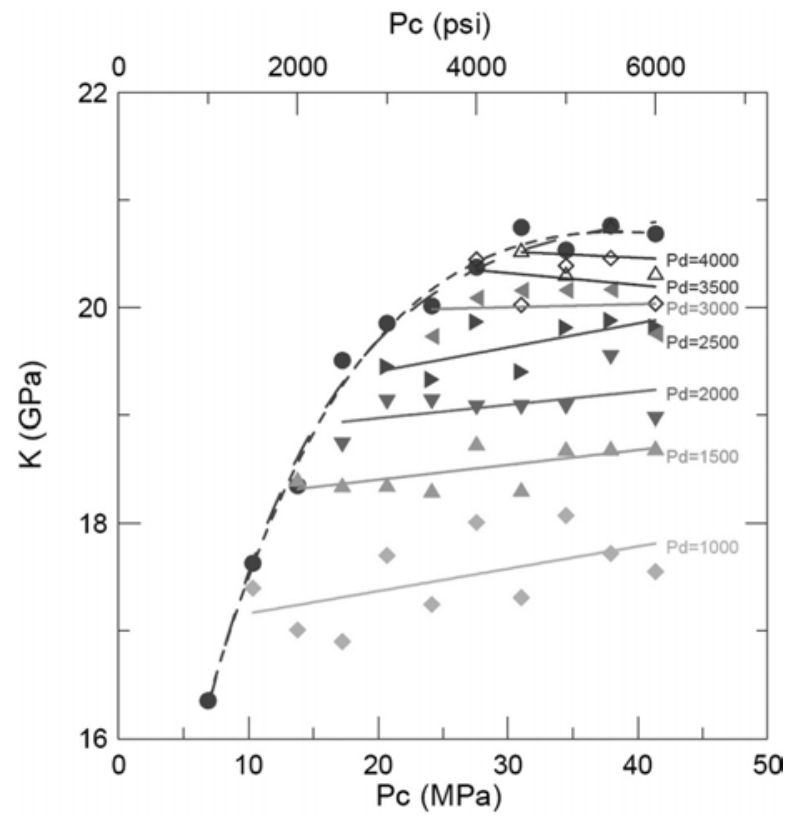

Figure $\mathbf{6}$ - Bulk modulus curves for sample 5005 as a function of confining pressure for zero porepressure (dots) along with constant differential pressure curves.

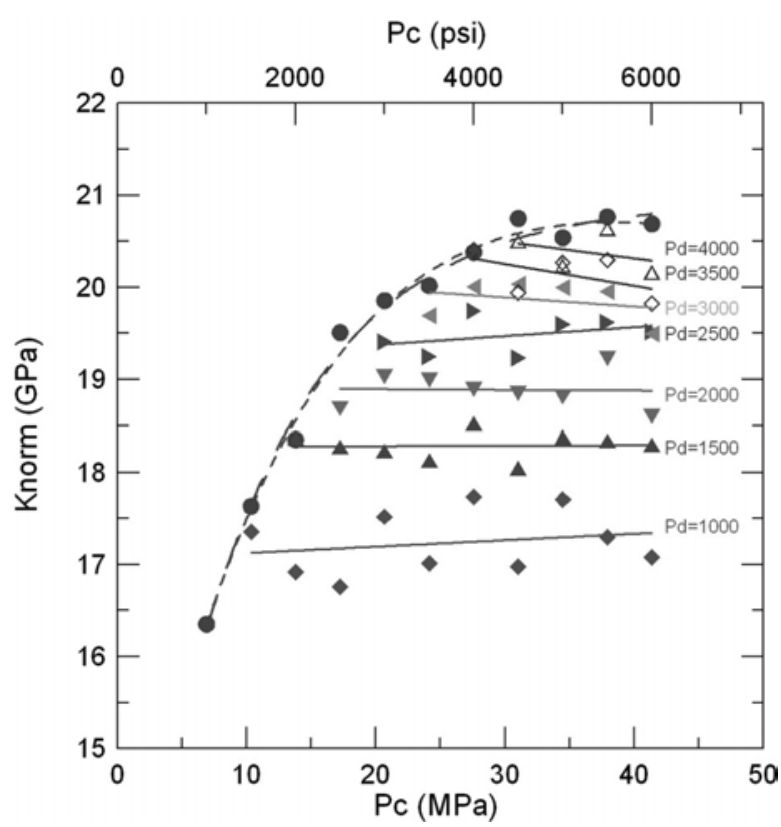

Figure 7 - Normalized bulk modulus curves for sample 5005 as a function of confining pressure for atmospheric porepressure (dots) along with constant differential pressure curves.

Figure 8 illustrates the effective pressure coefficients for the bulk modulus of sample 5005 before and after the normalization process among with the classical Biot-Willis coefficient for bulk compression of porous materials, given by Equation (5). We note that the empirical $n$ is greater than the Biot-Willis coefficient and that the $n$ values obtained after normalization of the bulk modulus 
are closer to one. Besides, there is a sharp variation on $n$ values at $2500 \mathrm{psi}$ and $3000 \mathrm{psi}$ (17.24 and $20.68 \mathrm{MPa}$, respectively) that needs a better understanding. We suspect that this may be associated with pore space alteration due to brine-calcite interaction and pressure cycling or with the presence of bi-modal porosity distribution. Pore compressibility experiments on neighbor samples, not shown in this article, also exhibits anomalous behavior around these pressures.

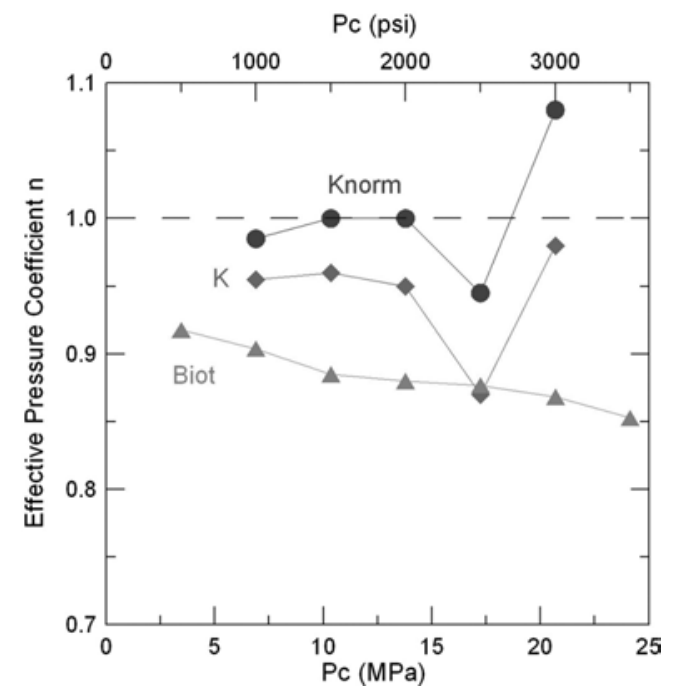

Figure 8 - Effective pressure coefficients for the bulk modulus of sample 5005 before (diamonds) and after (dots) the normalization process, among with the classical Biot-Willis coefficient for bulk compression of porous material, for atmospheric porepressure.

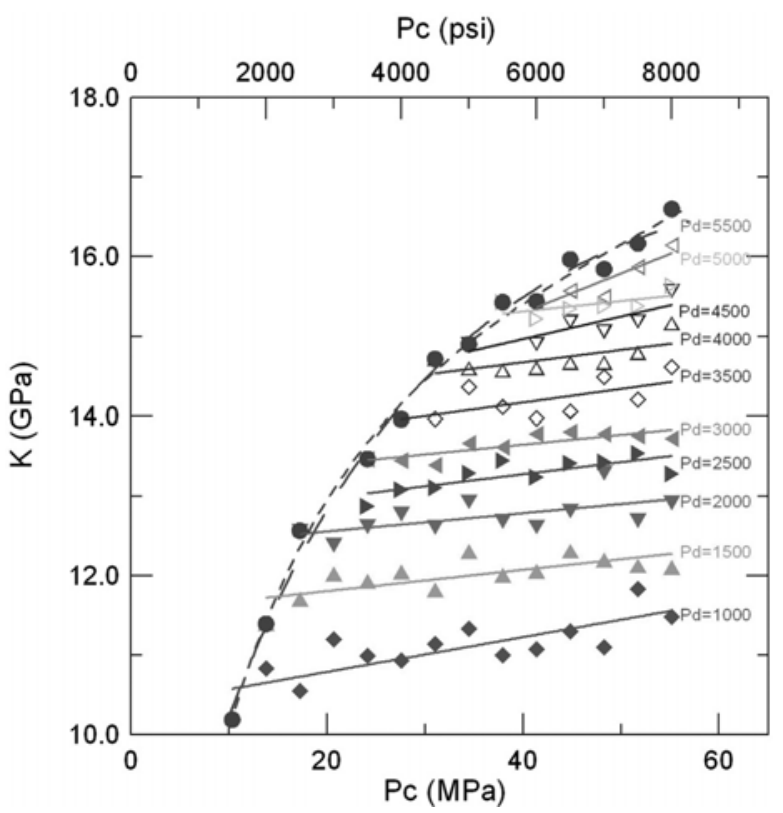

Figure 9 - Bulk modulus curves for sample 5062 as a function of confining pressure for porepressure vented to the atmosphere (dots) along with constant differential pressure curves.
Figures 9 and 10 show the behavior of the bulk and shear moduli for another limestone sample (5062) for various differential pressures along with the data for the pore system vented to the atmosphere (dots). The data are quite consistent.

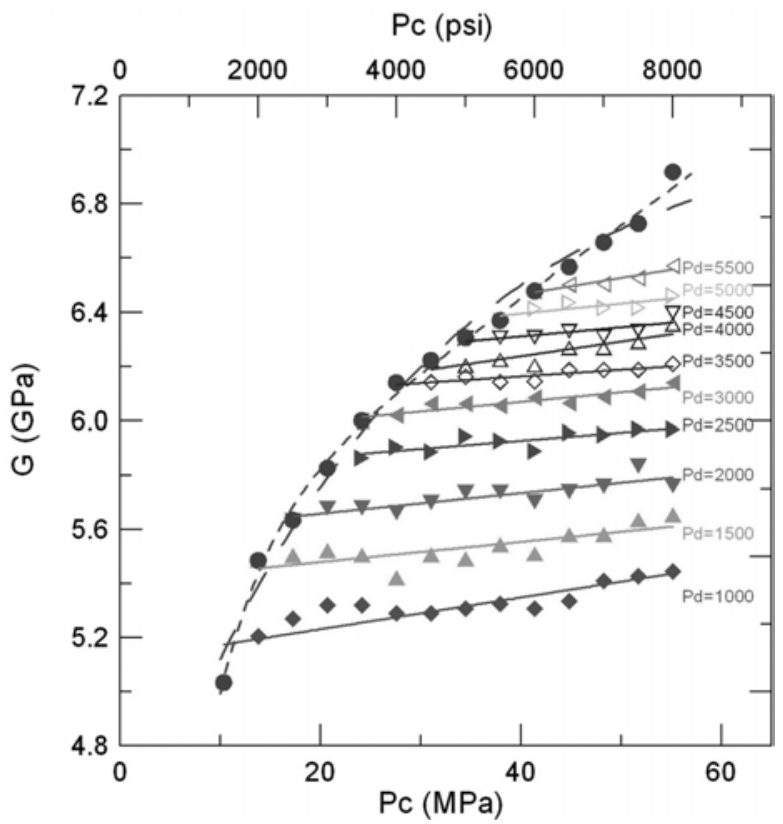

Figure 10 - Shear modulus curves for sample 5005 as a function of confining pressure for porepressure vented to the atmosphere (dots) along with constant differential pressure curves.

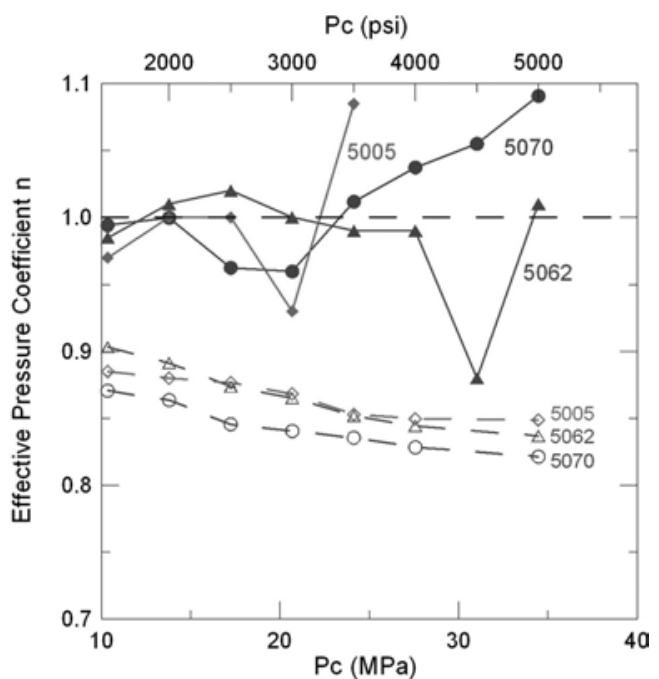

Figure 11 - Effective pressure coefficient for the normalized bulk modulus for three limestone samples at $500 \mathrm{psi}(3.45 \mathrm{MPa}$ ) porepressure. Dashed lines correspond to the Biot-Willis coefficient.

The results for the empirical porepressure coefficients referring to the normalized bulk modulus for the three samples that there is a complete set of measurements (compressional and shear-waves) was represented as a function of confining pressure in Figure 11. Note that the sample 5062 seems to have a wrong 
data at $4500 \mathrm{psi}(31.03 \mathrm{MPa})$. These data points are listed in Table 3. Figure 12 summarizes the results of effective pressure coefficients for the P-wave velocity for all the limestone samples, for a constant porepressure of $500 \mathrm{psi}(3.45 \mathrm{MPa})$. There are some evidences that $n$ depends on differential pressure.

Table 3 - Empirical effective pressure coefficients for the normalized bulk modulus of three limestone samples at $500 \mathrm{psi}(3.45 \mathrm{MPa}$ ) porepressure.

\begin{tabular}{|c|c|c|c|}
\hline $\mathrm{Pp}=500$ & \multicolumn{3}{|c|}{ Effective pressure coefficient $n$} \\
\hline $\mathrm{P}_{\mathrm{c}}$ (psi) & 5070 & 5062 & 5005 \\
\hline 1500 & 0.99 & 0.99 & 0.97 \\
\hline 2000 & 1.00 & 1.01 & 1.00 \\
\hline 2500 & 0.96 & 1.02 & 1.00 \\
\hline 3000 & 0.96 & 1.00 & 0.93 \\
\hline 3500 & 1.01 & 0.99 & 1.09 \\
\hline 4000 & 1.04 & 0.99 & \\
\hline 4500 & 1.05 & 0.88 & \\
\hline 5000 & 1.09 & 1.01 & \\
\hline
\end{tabular}

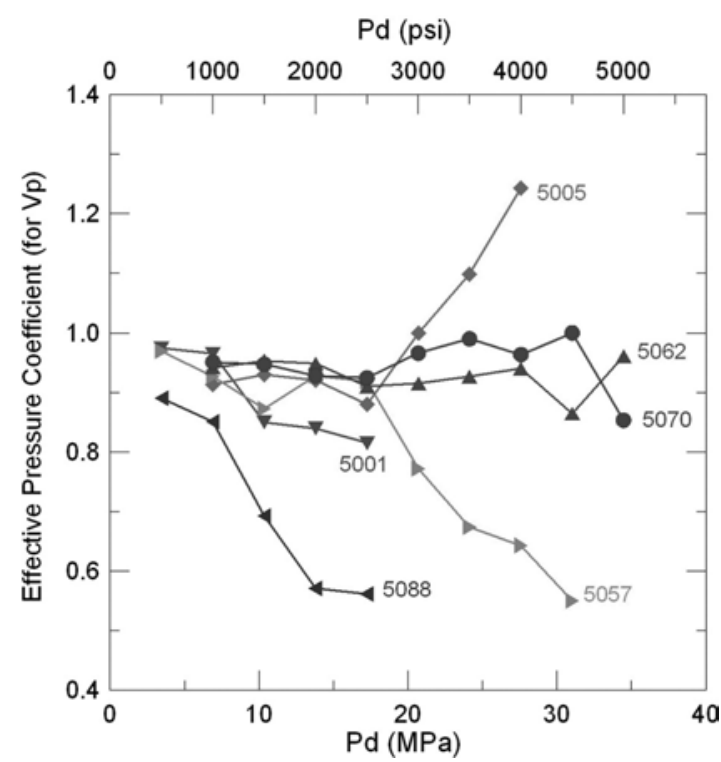

Figure 12 - Effective pressure coefficients for the compressional-wave velocity of the limestone samples for a constant porepressure of $500 \mathrm{psi}(3.45 \mathrm{MPa})$.

\section{Sandstones}

Due to the low permeability of the sandstone samples and the clorithe-brine interaction, that causes obliteration of pore-throats, it was difficult to obtain full water saturation by the imbibition method for all samples. The saturation was then estimated by weighting the sample before and after the saturation process and the fluid bulk modulus used for the calculations were estimated by the Wood's formula (compressibility equals to the weighted average of brine and air compressibilities).
The compressional and shear-wave velocity data for the sandstone $5976(\mathrm{Sw}=89 \%)$ are illustrated on Figures 13 and 14 , along with the curves for constant porepressures, atmospheric and $500 \mathrm{psi}$ (open dots and open diamonds). The compressionalwave velocity and bulk modulus for sample 5965 at various differential pressures are illustrated on Figures 15 and 16, along with the curve for $500 \mathrm{psi}(3.45 \mathrm{MPa})$ constant porepressure (open dots). The brine saturation for this sample was estimated to be $57 \%$.

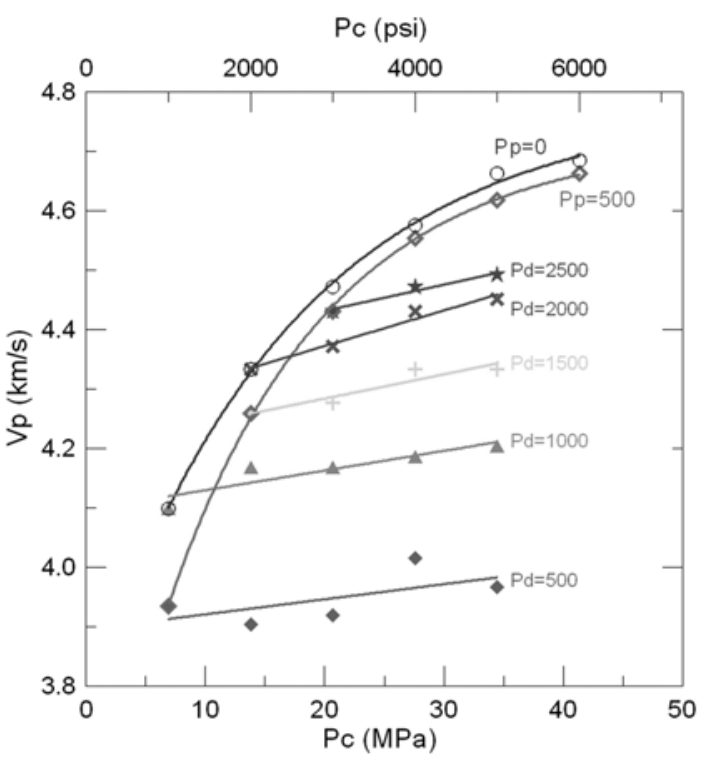

Figure 13 - Compressional-wave velocity as a function of confining pressure for sandstone sample 5976 for atmospheric and 500 psi porepressure (open dots and open diamonds) along with constant effective pressure curves.

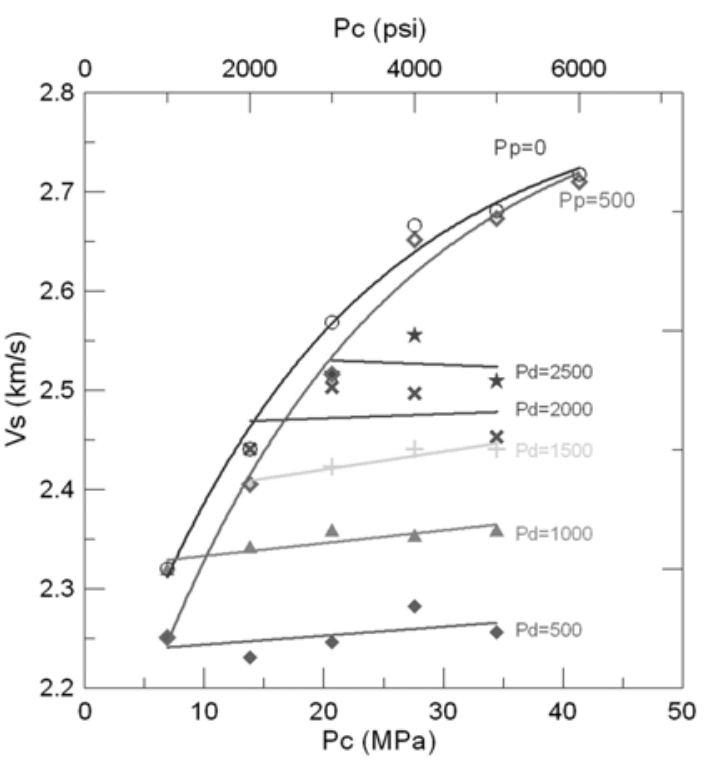

Figure 14 - Shear-wave velocity as a function of confining pressure for sandstone sample 5976 for atmospheric and 500 psi porepressure (open dots and open diamonds) along with constant effective pressure curves. 
The effective pressure coefficients for compressional-wave velocity for all the sandstones samples are shown on Figure 17 as a function of porepressure for a constant confining pressure $2500 \mathrm{psi}(17.24 \mathrm{MPa})$. As can be noted, it seems that the $n$ values depend on porepressure itself. This is another issue on time-lapse studies.

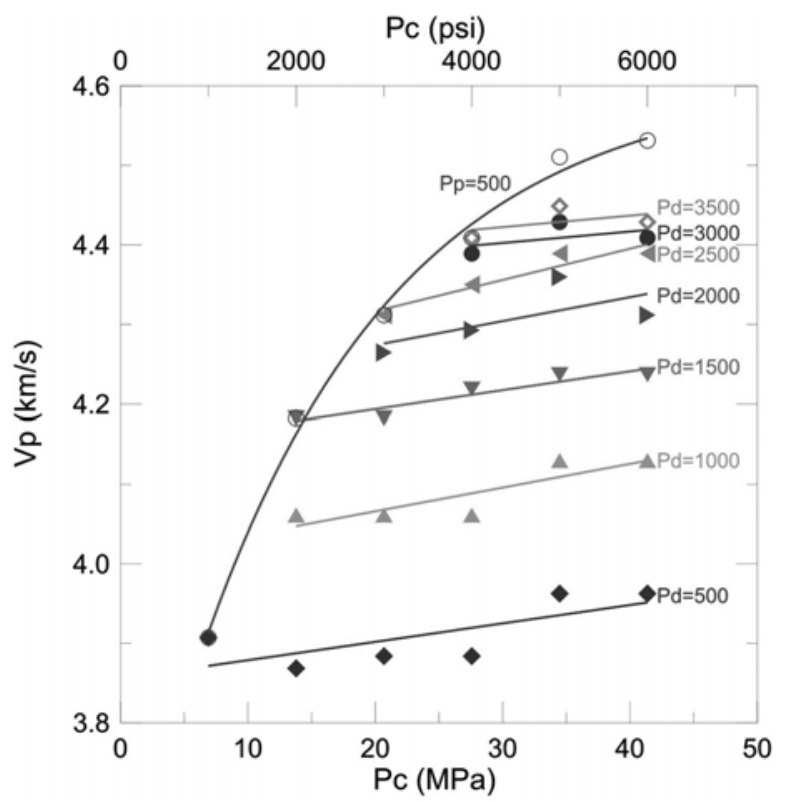

Figure 15 - Compressional-wave velocity for sample 5965 at various differential pressures along with the curve for $500 \mathrm{psi}(3.45 \mathrm{MPa}$ ) constant porepressure (open dots)

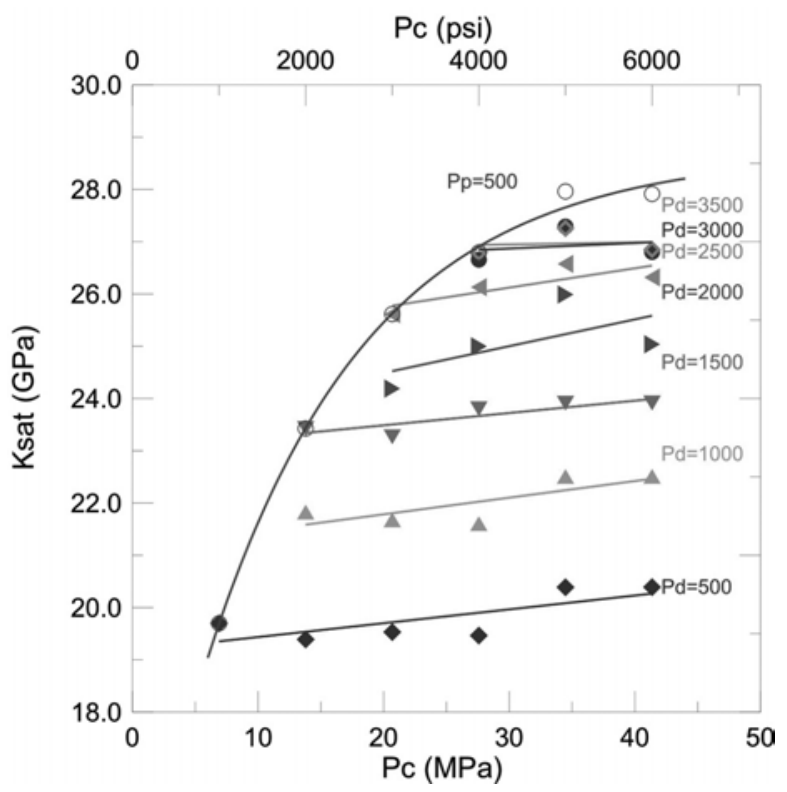

Figura 16 - Bulk modulus for sample 5965 at various differential pressures along with the curve for $500 \mathrm{psi}$ (3.45 MPa) constant porepressure (open dots).

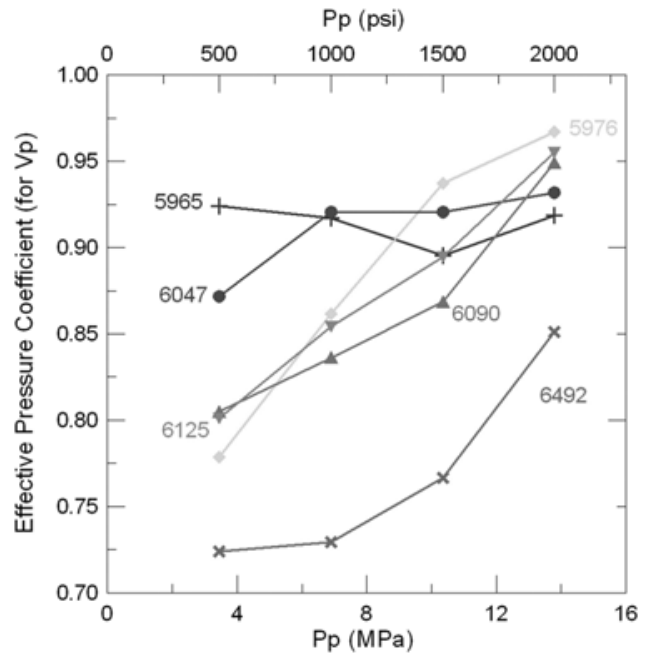

Figure 17 - Effective pressure coefficients for the compressional-wave velocity for all the sandstones samples as a function of porepressure for a constant confining pressure $2500 \mathrm{psi}(17.24 \mathrm{MPa})$.
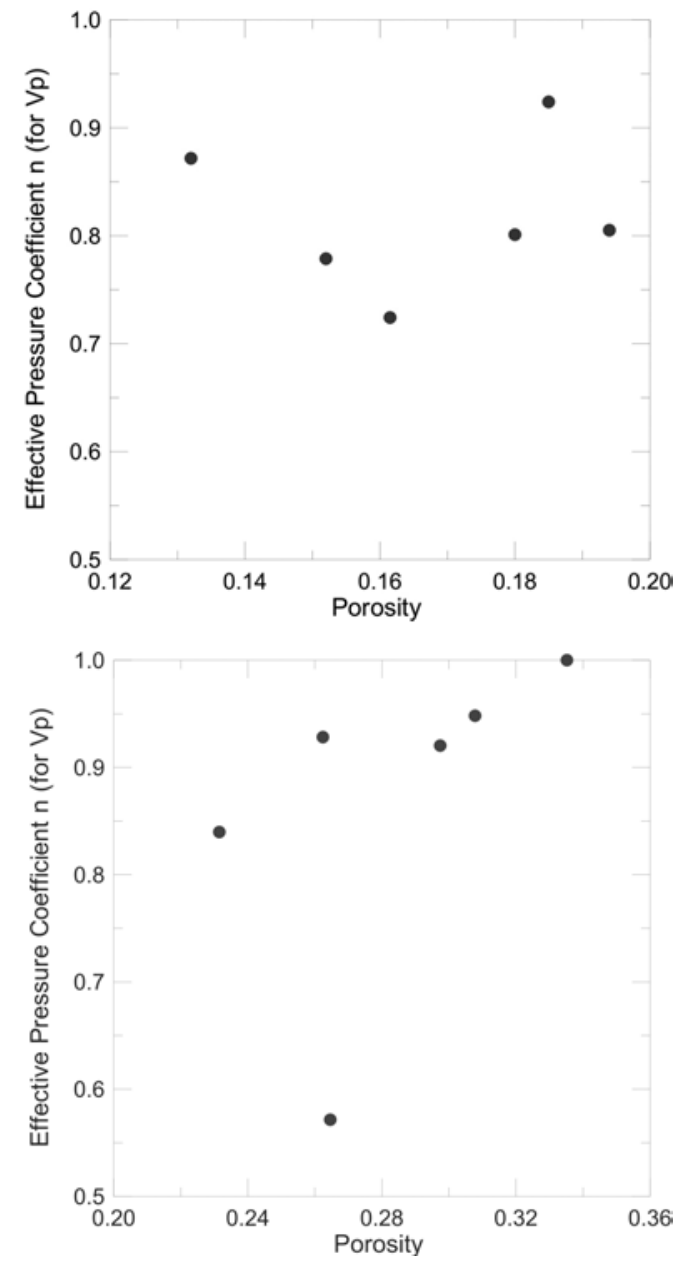

Figure 18 - Effective pressure coefficient as a function of porosity for the (a) sandstone and (b) limestone samples (porepressure 500 psi, confining pressure 2500 psi). 
It is interesting to compare the $n$ coefficients for the sandstone and limestone samples. Figure 18 (a) and (b) summarizes the $n$ values obtained for the compressional-wave velocity of the sandstones and limestones, respectively, as a function of porosity, for a porepressure of $500 \mathrm{psi}(3.45 \mathrm{MPa}$ ) and confining pressure of $2500 \mathrm{psi}(17.24 \mathrm{MPa})$. The data points are listed on Table 4. In spite of the data scattering, there is a trend of increasing $n$ with porosity even considering the different kinds of rock composition and texture.

Table 4 - Effective pressure coefficients $n$ for the compressional-wave velocity of the sandstone and limestone samples at $2500 \mathrm{psi}$ (17.24 MPa) confining pressure and $500 \mathrm{psi}(3.45 \mathrm{MPa}$ ) porepressure with the porosity $\phi$ (decimal units).

\begin{tabular}{|c|c|c|c|}
\hline Rock type & Sample & $n$ & $\phi$ \\
\hline \multirow{5}{*}{ Sandstone } & 6047 & 0.87 & 0.1320 \\
\cline { 2 - 4 } & 5976 & 0.78 & 0.1520 \\
\cline { 2 - 4 } & 6492 & 0.72 & 0.1615 \\
\cline { 2 - 4 } & 6125 & 0.8 & 0.1800 \\
\cline { 2 - 4 } & 5965 & 0.92 & 0.1850 \\
\cline { 2 - 4 } & 6090 & 0.81 & 0.1940 \\
\hline \multirow{5}{*}{ Limestone } & 5001 & 0.84 & 0.2315 \\
\cline { 2 - 4 } & 5070 & 0.93 & 0.2624 \\
\cline { 2 - 4 } & 5088 & 0.57 & 0.2646 \\
\cline { 2 - 4 } & 5005 & 0.92 & 0.2974 \\
\cline { 2 - 4 } & 5062 & 0.95 & 0.3078 \\
\cline { 2 - 4 } & 5058 & 1.00 & 0.3352 \\
\hline
\end{tabular}

\section{DISCUSSION}

It was found effective pressure coefficients $n$ different than unity, even for the high porosity limestone samples.

The values reported here for the effective pressure coefficient are relatively close to unity when compared to those reported by Xu et al. (2006), that obtained $n$ values as low as 0.3 for Lyons sandstone, that is a clean tight sandstone. It must be remembered that our limestone samples are very porous, unconsolidated and that the pore space is well communicated. On the other hand, our sandstone samples are very well consolidated and have relatively low permeability, with much of the porosity contained on shales.

This deviation of the effective pressure coefficient from unit can lead to erroneous porepressure interpretation from timelapse data and even on the feasibility study phase or on geopressure prediction. The error due to the $n$ value comes from the fact that, for some porepressure variation $\Delta P_{p}$, assuming a constant confining pressure, the effective pressure variation is $\Delta P_{e f}=-n \Delta P_{p}$, while the differential pressure variation is $\Delta P_{d}=-\Delta P_{p}$. As an example, for $n=0.8$ the variation of differential pressure is $25 \%$ greater than the variation on the ef- fective pressure. So, for an observed change in the porepressure, we would have an overestimation of changes in bulk modulus. On the other hand, an observed change in seismic velocity or impedance would lead to underestimates of the porepressure variation. The error does not depend only on the $n$ values, but also on the velocity-pressure sensitivity for the particular reservoir.

Although the $n$ values for the unconsolidated limestone are not so far from unity, it has a stronger pressure sensitivity of velocities and elastic moduli when compared to consolidated rocks, so that any pressure variation should correspond to a large variation on the elastic property.

Another important issue is that the effective pressure coefficient seems to depend on the porepressure, so that for each timestep on a 4D study, a different $n$ value must be considered.

\section{CONCLUSIONS}

We measured the effective pressure coefficients for the seismic velocities and elastic moduli of Brazilian limestones and sandstones. The results show that, even for unconsolidated rocks, there is a deviation of the effective pressure coefficient from unity that can lead to errors on porepressure prediction from seismic data and also on time-lapse studies. These striking results are the first obtained for Brazilian rocks. Nevertheless, more experimental investigations with different rock and fluid types are needed in order to obtain a better understanding of the effective pressure coefficients and its influences on pressure estimation from seismic data.

\section{ACKNOWLEDGEMENTS}

The authors thank Petrobras for the permission to present this paper. We are strongly in debt also with the geologists Miguel Pittella Franco and Dorval Dias Filho for the geological description of the samples and useful discussions as well as with Angela Vasquez for revising the manuscript and giving valuable suggestions.

\section{REFERENCES}

BATZLE M \& WANG Z. 1992. Seismic properties of pore fluids. Geophysics, 57: 1396-1408.

BERRYMAN JG. 1992. Effective stress for transport properties of inhomogeneous porous rock. J. Geophys. Res., 97: 17409-17424.

BERRYMAN JG. 1993. Effective stress rules for pore-fluid transport in rocks containing two minerals. Int. J. Rock Mech. Min. Sci. \& Geomech. Abst., 30: 1165-1168.

BIOT MA. 1955. Theory of propagation of elastic waves in a fluid saturated porous solid. II. Higher frequency range. J. Acoust. Soc. Am., 28: 179-191. 
BIOT MA \& WILLIS DG. 1957. The elastic coefficients of the theory of consolidation. J. Appl. Mech., ASME, 24: 594-601.

CHRISTENSEN NI \& WANG HF. 1985. The influence of pore pressure and confining pressure on dynamic elastic properties of Berea Sandstone. Geophysics, 50: 207-213.

EBERHART-PHILLIPS D, HAN DH \& ZOBACK MD. 1989. Empirical relationships among seismic velocity, effective pressure, porosity, and clay content in sandstone. Geophysics, 54: 82-89.

GASSMANN F. 1951. On Elasticity of Porous Media. In: PELISSIER MA, HOEBER H, COEVERING N \& JONES IF (Eds.). Classics of Elastic Wave Theory. SEG Geophysics Reprint Series No. 24, SEG, 389-407.

GUREVICH B. 2004. A simple derivation of the effective stress coefficient for seismic velocities in porous rocks. Geophysics, 69: 393-397.

KING MS. 1966. Wave velocities in rocks as a function of overburden pressure and pore fluid saturants. Geophysics, 31: 56-73.

LADE PV \& DE BOER R. 1997. The concept of effective stress for soil, concrete and rock. Géotechnique, 47: 61-78.

MAVKO G. 2004. Seismic Fluid Detection, Reservoir Delineation, and Recovery Monitoring: The Rock Physics Basis. Course presented at the $74^{\text {th }}$ SEG Meeting, October 9-10, Denver, Colorado. 327 pp.

NUR A \& BYERLEE JD. 1971. An exact effective stress law for elastic deformation of rocks with fluids. J. Geophys. Res., 76: 6414-6419.

PRASAD M \& MANGHNANI M. 1997. Effects of pore and differential pressure on compression wave velocity and quality factor in Berea and Michigan sandstones. Geophysics, 62: 1163-1176.

SKEMPTON AW. 1960. Significance of Terzaghi's concept of effective stress. In: TERZAGHI K (Ed.). From Theory to Practice in Soil Mechanics. John Wiley \& Sons Inc. 425 pp.

STANDIFIRD W, MATTHEWS M \& PAINE K. 2004. Optimized basin modeling for geopressures. Petroleum Africa, December 2004: 6-10.

TERZAGHI K, PECK RB \& MESRI G. 1996. Soil Mechanics in Engineering Practice, $3^{\text {rd }}$ edition. John Wiley \& Sons Inc. 592 pp.

TODD T \& SIMMONS G. 1972. Effect of pore pressure on the velocity of compression waves in low-porosity rocks. J. Geophys. Res., 77: 3731-3743.

VASQUEZ GF, SIMÕES FILHO IA, BRUHN CHL \& DILLON LD. 2000. Viscoelastic behavior of a Brazilian turbidite reservoir and its relationships to facies attributes. In: $70^{\text {th }}$ Annual International Meeting. SEG. Expanded Abstracts: 1927-1930.

VASQUEZ GF, VARGAS E, LEÃO M, BACELAR C, JUSTEN J \& ALVES I. 2007. Effective pressure coefficients of some Brazilian rocks. In: Tenth International Congress of the Brazilian Geophysical Society. November 19-23, Rio de Janeiro, Brazil. CD-ROM.

XU X, HOFMANN R, BATZLE M \& TSHERING T. 2006. Influence of pore pressure on velocity in low-porosity sandstone: Implications for time-lapse feasibility and pore-pressure study. Geophys. Prospect., 54 : $565-573$.

\section{NOTES ABOUT THE AUTHORS}

Guilherme Fernandes Vasquez holds a BSC in Physics from Universidade Federal do Rio de Janeiro (UFRJ, 1988) and a MSc in Reservoir Engineering from Universidade Estadual de Campinas (UNICAMP, 1999). He joined Petrobras in 1989 and currently works at the Petrobras' Research Centre in Geophysics, acting in research projects and technical support. He develops studies especially on rock physics, rock-log-seismic calibration, time-lapse seismic and geomechanics' effects on rock velocities. Some of these studies are being conducted in collaboration with the researchers from the Geology Department of Federal University of Rio de Janeiro.

Eurípedes do Amaral Vargas Junior holds a BSc in Civil Engineering from Universidade de São Paulo (USP, 1972), and a MSc in Geotechnical Engineering from Pontíficia Universidade Católica do Rio de Janeiro (PUC-Rio, 1975) as well as MSc and PhD in Rock Mechanics from the Imperial College, University of London (1978 and 1988, respectively). He is currently professor at the Departamento de Engenharia Civil from Pontíficia Universidade Católica do Rio de Janeiro and at the Geology Department of Federal University of Rio de Janeiro, where he is working developing research studies on Environmental Geotechnics, Petroleum Geomechanics and Rock Mechanics.

Cleide Jeane Bacelar Ribeiro holds a BSc in Civil Engineering from Universidade Estadual de Feira de Santana (UEFS, 1996) and a MSc as well as a PhD in Civil Engineering from Pontifícia Universidade Católica do Rio de Janeiro (PUC-Rio, 1999 and 2003, respectively). Former engineering professor in Universidade Federal Fluminense, she joined the Petrobras rock physics team in 2004.

Marcos de Leão Silva has background in electronics and had worked several years at Petrobras' seismic crews. He joined the rock physics laboratory staff in 1991 and acts in research studies as well as on lab equipment development.

Julio Cesar Ramos Justen holds a BSc in Geology from Universidade Federal do Rio de Janeiro (UFRJ, 2001) and works at the Petrobras petro seismic laboratory developing research studies and technical support in rock physics, time-lapse seismic and seismic properties of shales. 